\title{
Bioremediation of Crude Oil Contaminated Soil Using Cow Dung
}

\author{
O. E. Oludele ${ }^{1}$, M. E. Wyse ${ }^{1}$, O. K. Odeniy ${ }^{1,2}$, \\ P. O. Ali ${ }^{3}$, M. Kugbogbenmowei ${ }^{1}$
}

\begin{abstract}
${ }^{1}$ Industrial Safety and Environmental Technology (ISET) Department, Petroleum Training Institute, P.M.B 20 Effurun Delta state Nigeria

${ }^{2}$ Department of Environmental Management and Toxicology (EMT), Federal University of Petroleum Resources, P.M.B 1221 Effurun, Delta state Nigeria

${ }^{3}$ Department of Science Laboratory Technology (SLT), Petroleum Training Institute, P.M.B 20 Effurun, Delta state Nigeria
\end{abstract}

\begin{abstract}
Crude oil contaminated soils were obtained from an oil pit in Burutu L.G.A. of Delta State and the Cow dung was collected from Garki slaughterhouse along Benin-Sapele-Warri road Delta, Nigeria. The samples were sundried for a period of one week and kept in the laboratory. 500g of crude oil contaminated soil was weighed into four different containers labeled A, B, C and D. The soil was amended with the application of cow dung at various weights of $100 \mathrm{~g}, 150 \mathrm{~g}$ and $200 \mathrm{~g} / \mathrm{kg}$ respectively leaving sample D without amendment which served as the control for a period of 10 weeks. The microbiological and physiological analysis of crude oil contaminated soil amended with cow dung was investigated using standard cultural techniques. The Total Heterotrophic Bacterial count for the samples A, B, C and D treatment options increased from $\left(8.1 \times 10^{6}-9.2 \times 10^{6} \mathrm{cfu} / \mathrm{g}\right),\left(8.1 \times 10^{6}-9.5 \times 10^{6} \mathrm{cfu} / \mathrm{g}\right),\left(8.1 \times 10^{6}-\right.$ $\left.9.6 \times 10^{6} \mathrm{cfu} / \mathrm{g}\right)$ and $\left(8.1 \times 10^{6}-8.9 \times 10^{6} \mathrm{cfu} / \mathrm{g}\right)$ respectively. The Total Hydrocarbon Utilizing Bacterial Count for the $\mathrm{A}, \mathrm{B}, \mathrm{C}$, and D treatment options increased from $\left(4.2 \times 10^{6}-7.6 \times 10^{6} \mathrm{cfu} / \mathrm{g}\right),\left(4.2 \times 10^{6}-8.0 \times 10^{6} \mathrm{cfu} / \mathrm{g}\right),\left(4.2 \times 10^{6}-8.5 \mathrm{x}\right.$ $\left.10^{6} \mathrm{cfu} / \mathrm{g}\right)$ respectively and sample $\mathrm{D}$ control increased slightly $\left(4.2 \times 10^{6}-4.9 \times 10^{6}\right)$. The Nitrate concentration increased from $(0.04 \mathrm{mg} / \mathrm{kg}$ to $0.11 \mathrm{mg} / \mathrm{kg})$. Phosphate concentration also increased from $(1.72 \mathrm{mg} / \mathrm{kg}$ to $5.72 \mathrm{mg} / \mathrm{kg})$. Percentage loss of total hydrocarbon for the three treatment options A, B and C at the end of 10 weeks were $29.3 \%$, $44.13 \%$ and $68 \%$ respectively. From the results obtained it can be concluded that cow dung has demonstrated high potential in enhancing bioremediation of crude oil contaminated soil.
\end{abstract}

\section{Introduction}

The exploration activities such as drilling, refining, transportation and so on of crude oil generates large amount of environmental waste. These activities can cause severe environmental degradations known to affect both terrestrial and aquatic biota which constitutes majorly as a source of human livelihood and home to several species. [1]. The adverse effects of crude oil on soil cannot be overemphasized. Phosphorus and nitrogen contents decreases when crude oil is present in the soil even though, crude oil provides to the soil excessive hydrocarbon that affects soil enzymatic activities due to the inability of soil microbes to degrade the excess hydrocarbons $[2,3,4]$. Once the soil has been degraded, it is usually difficult to bring it back to its original state. Bioremediation is one method that has been reported to be effective in removing numerous pollutants from many contaminated sites. [5,6,7]. This method, refers to the use of natural occurring microorganisms or genetically isolated microorganisms by man to detoxify man-made pollutants. Bioremediation relies on bacteria, plants and fungi to degrade, breakdown, transform or remove contaminants or impairments of quality from the contaminated soil and water $[8,9]$. Biostimulation is the addition of substrates, vitamins, oxygen and other compounds that stimulate microorganism activities so that they can degrade the petroleum hydrocarbons faster. When nutrients such as animal dung are added, the microorganisms can rapidly degrade the oil, utilizing it as the carbon source [10]. In this research, crude oil contaminated soils were treated with different quantity of cow dung as stimulant to speed up the bioremediation of the crude oil in the soil by the microorganisms present.
Materials and Methods
Demographic description of Sample area
The contaminated soil was collected from an oil pit located in Ogulagha, Forcados terminal, Burutu L.G.A., Delta State. Which has coordinate Latitude: $5.357^{\circ}$ and Longitude: $5.347^{\circ} \mathrm{E}$. The cow dung was collected from Garki slaughterhouse in Benin-Sapele- Warri road delta, Nigeria, which has coordinate latitude: N5 36 '2.77” and Longitude: E5 ${ }^{\circ} 46^{\prime} 46.31$ '. 


\section{Soil sample and cow dung treatment}

The crude oil contaminated soil was sun dried for a period of one week to remove moisture thereafter gently crushed and sieved through a $2 \mathrm{~mm}$ mesh sieve in order to remove non-soil particles and debris. The cow dung was also sun-dried for one week and thereafter sieved to remove impurities. A portion of the sieved soil and cow dung was then used to determine the baseline physical and chemical parameters of the soil and cow dung.

\section{Experimental Design}

$500 \mathrm{~g}$ of the sieved crude oil contaminated soil was weighed into four different clean plastic bowl labeled $\mathrm{A}, \mathrm{B}, \mathrm{C}$ and D respectively. In addition, $100 \mathrm{~g}, 150 \mathrm{~g}$ and $200 \mathrm{~g}$ of sieved cow dung were then added to each of the crude oil contaminated soil in the plastic bowls labelled A, B and C and mixed thoroughly. Bowl D was left as the control; without amendment. The moisture content of each bowl was adjusted to $60 \%$ by the addition of water and the content of each plastic bowls was tilled using sterilized spatula three times a week for proper aeration. The plastic bowls were incubated in the Biology/Microbiology Laboratory of Petroleum Training institute, Delta state at room temperature $\left(30 \pm 2^{\circ}\right)$ in triplicates.[10] The set up was then left for a period of 10 weeks while the microbial, physiochemical and TPH analysis were carried out at the zero week and subsequently at two-week intervals.

\section{Determination of Total Petroleum Hydrocarbon}

$10 \mathrm{~g}$ of the soil sample was weighed each into $100 \mathrm{ml}$ beaker. To sample, $10 \mathrm{ml}$ of each of $\mathrm{n}$-Hexane, Dichloromethane and Acetone were added. The beaker was then placed on a mechanical shaker for 30 minutes to gently mix the mixtures. The mixture was then agitated and solvent extracted using a sonicator. The extract was then filtered. The final volume of the extracts was taken and stored in clean small bottles. A sample of the extract was then withdrawn with automated gas tight syringe of the auto-sampler and analyzed by direct injection into the Gas chromatography (GC) - FID preset at specific condition. The Analysis was allowed to run and data were quantified at the end of the analysis.

Instrument reading $\mathrm{x}$ Total weight of extract

$$
=\quad \text { Weight of sample }
$$

\section{Enumeration of Soil Bacteria}

Soil samples from each oil polluted soil were taken every 14 days for the enumeration of Total Heterotrophic Bacteria (THB). Samples were diluted and $0.1 \mathrm{ml}$ were plated on nutrient agar medium (Lab M) for isolation of THB with the addition of $50 \mu \mathrm{g} / \mathrm{ml}$ nystatin to suppress the growth of fungi. Plates were incubated at $30^{\circ} \mathrm{C}$ for 24 hours before the colonies were counted. Hydrocarbon utilizing bacteria (HUB) in the soil samples were enumerated using oil agar. (1.8g K ${ }_{2} \mathrm{HPO} 4,4.0 \mathrm{~g} \mathrm{NH}_{4} \mathrm{Cl}, 0.2 \mathrm{~g} \mathrm{MgSO}_{4} .7 \mathrm{H} 2 \mathrm{O}, 1.2 \mathrm{~g}$ $\mathrm{KH}_{2} \mathrm{PO}_{4}, 0.01 \mathrm{~g} \mathrm{FeSO}_{4} .7 \mathrm{H} 2 \mathrm{O}, 0.1 \mathrm{~g} \mathrm{NaCl}, 20 \mathrm{~g}$ agar, $1 \mathrm{ml}$ used sterilized engine oil in $1000 \mathrm{ml}$ distilled water)[11].The oil agar plates were incubated at $30^{\circ} \mathrm{C}$ for 5 days before the colonies were counted. The bacterial colonies were randomly picked, and pure culture was obtained by repeated sub-culturing on nutrient agar (Lab M). The bacterial isolates were characterized using microscopic techniques (morphological characteristics) and biochemical tests.

\section{Results and Discussion}

The physicochemical properties of the soil and the cow dung used in the experimental procedure are written in Table 1.0 below

Table 1.0: Result of the physicochemical properties of the soil sample and the cow dung used for bioremediation

\begin{tabular}{llc}
\hline PARAMETERS & Soil & Cow dung \\
\hline pH & 8.0 & 7.0 \\
Nitrogen (\%) & 0.04 & 0.53 \\
Phosphate (mg/kg) & 1.72 & \\
TPH (mg/kg) & 4550.08 & \\
THB (cfu/g) & $8.1 \times 10^{6}$ & \\
HUB (cfu/g) & $4.2 \times 10^{6}$ & \\
\hline
\end{tabular}

Biodegradation of crude oil

The biodegradation of crude oil contaminated soil through out the study period of 70 days is shown in figure 1 below 


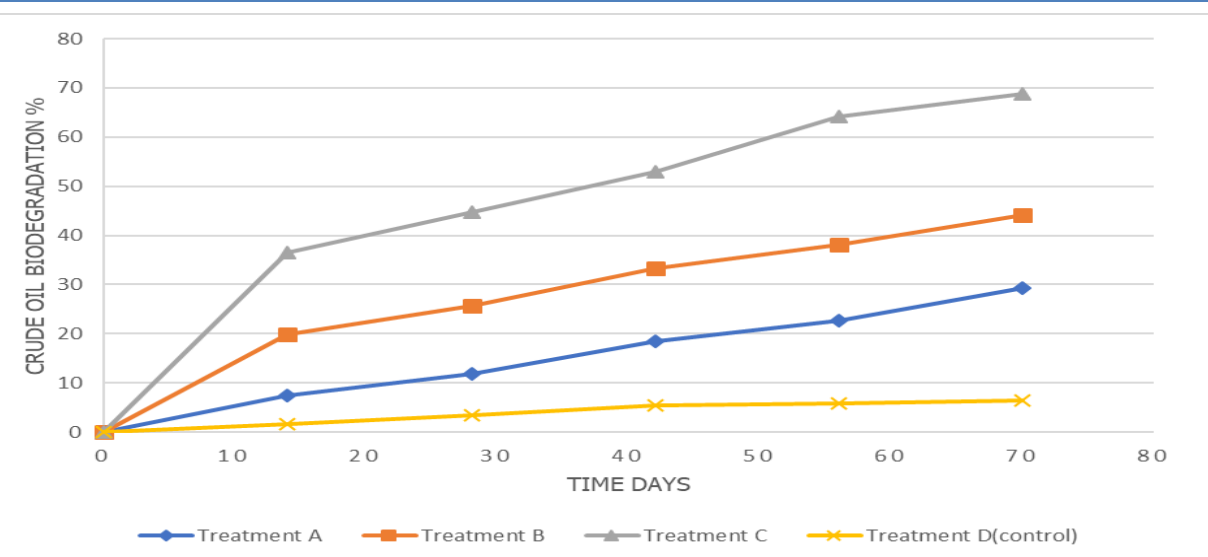

Fig.1. Percentage biodegradation of Total Petroleum Hydrocarbon in hydrocarbon contaminated with different quantity of cow dung (Sample A, B and C) and the control treatment without the crude oil (Sample D) for 10 weeks.

From Figure 1 above, the result showed high biodegradation of the hydrocarbon after the 10 weeks for each of the soil amended with cow dung compared to the control soil treatment. At the end of the 10 weeks, treatment $\mathrm{C}$ showed the highest percentage of crude oil degradation with $68 \%$ followed by treatment B which was $44.13 \%$ and treatment A with the least amount of cow dung showed the least degradation of $29.34 \%$. When compared with the control sample without the amendment, which showed $6.52 \%$ of degradation of crude oil, Treatment (A,B and C) all performed relatively well. The highest degradation was observed at the end of the 10 weeks for all the treatment and the control. Similar result trend was obtained by [11]

The main difference in the oil degradation between the soil amended (Sample A,B and C) and the control (Sample D) is seen between the 1-14 days, where biostimulation resulted in significant increase in oil biodegradation. The reason for the results obtained might be due to differences in the nutrient contents, particularly $\mathrm{N}$ and $\mathrm{P}$ in the cow dung in stimulating the indigenous microorganisms. Addition of $\mathrm{N}$ and $\mathrm{P}$ to an oil polluted soil has been shown to accelerate the biodegradation of the petroleum in soil [12]

Table 2: TPH value in Hydrocarbon contaminated soil with different quantity of cow dung (Treatment A, B and C) and the control sample without the cow dung (Treatment D) for 10 weeks

\begin{tabular}{|c|c|c|c|c|}
\hline $\begin{array}{c}\text { Duration } \\
\text { (Days) }\end{array}$ & Treatment A & Treatment B & Treatment C & $\begin{array}{c}\text { Treatment D } \\
(\text { Control })\end{array}$ \\
\hline 0 & 4550.08 & 4550.08 & 4550.08 & 4550.08 \\
\hline 14 & 4215.36 & 3650.75 & 2885.23 & 4480.32 \\
\hline 28 & 4007.74 & 3381.56 & 2517.06 & 4393.56 \\
\hline 42 & 3712.13 & 3034.60 & 2141.85 & 4300.25 \\
\hline 56 & 3521.32 & 2817.34 & 1634.31 & 4281.34 \\
\hline 70 & 3214.76 & 2541.92 & 1423.51 & 4253.56 \\
\hline
\end{tabular}

Figure 2 and 3 below shows the increase in the Nitrate $(\mathrm{N})$ and Phosphate $(\mathrm{P})$ quantity present in each of the treatment with the control throughout the 10 weeks period. Treatment $\mathrm{C}$ with the highest amendment of cow dung showed the highest increase in $\mathrm{N}(0.04-0.2)$ and $\mathrm{P}(1.72-7.21)$ throughout the period under observation. This was followed by treatment $\mathrm{B}$ and then $\mathrm{A}$. The control treatment $\mathrm{D}$, showed a slight increase in the Nitrate from 0.04 to 0.06 while the Phosphate decrease significantly from 1.72 to 1.5 during the 10 weeks period. $\mathrm{N}$ and $\mathrm{P}$ are known as most important nutrients needed by hydrocarbon utilizing bacteria to carry out effective and efficient biodegradative activities of xenobiotics in the soil environment. Similar results were observed in hydrocarbon contaminated soils amended with poultry and pig manure compost $[13,14]$.

The $6.52 \%$ oil biodegradation observed in control soil without any amendment might be due to non biological factors such as, evaporation or photodegradation. 
The Implementation of Computerized Physician Order Entry in the Intensive Care Unit

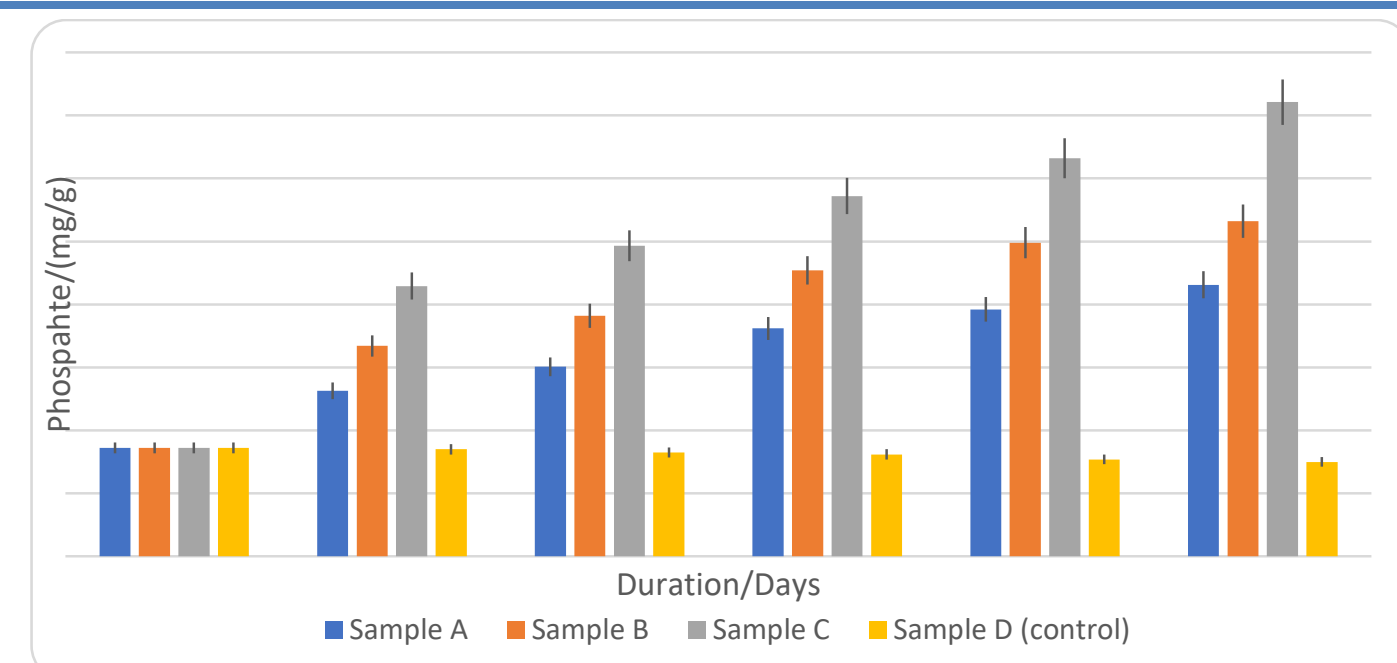

Fig.2. Increase in the Phosphate concentration $(\mathrm{mg} / \mathrm{g})$ in soil contaminated with of crude oil with different quantity of cow dung treatment (Sample A, B and C) and the control treatment without the cow dung (Sample D) for 10 weeks

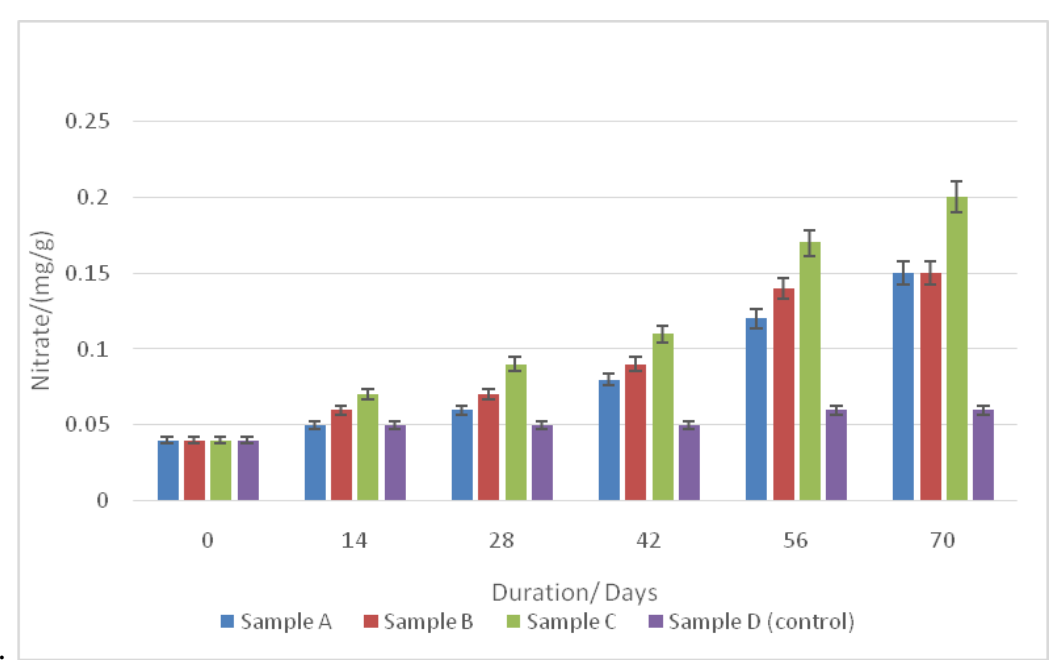

Fig. 3. Nitrate concentration $(\mathrm{mg} / \mathrm{g})$ in crude oil contaminated soil with different quantity cow dung (Sample A, $B$ and $C$ ) and the control treatment without the cow dung (Sample D) for 10 weeks

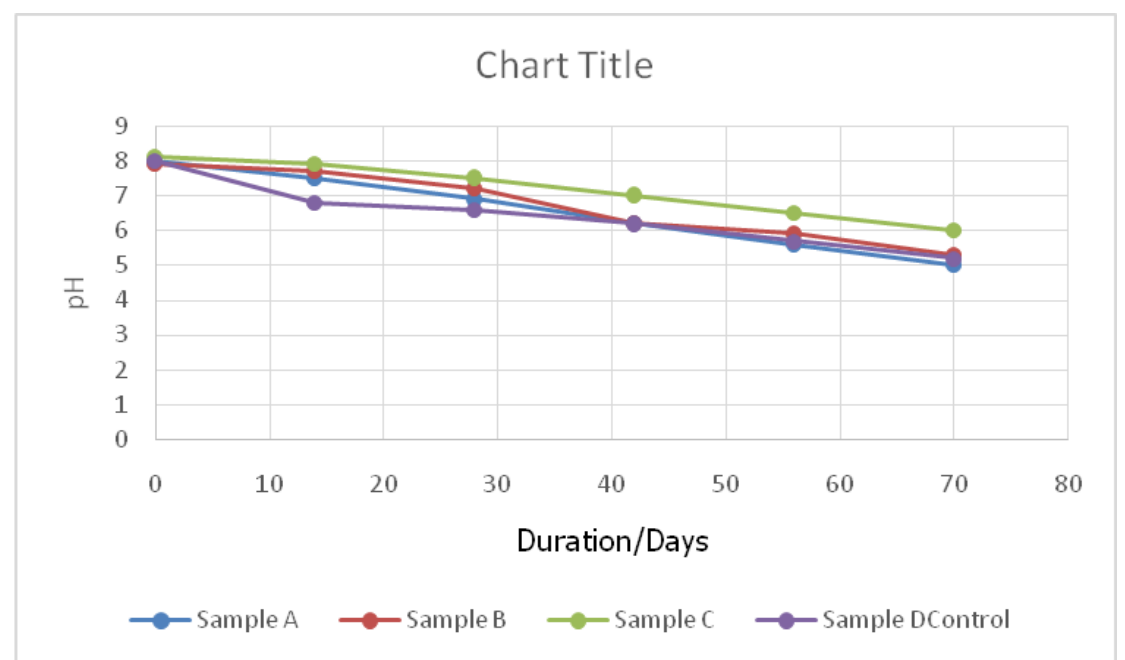

Fig.4. $p H$ in crude oil contaminated soil with different quantity cow dung (Sample A, B and C) and the control treatment without the cow dung (Sample D) for 10 weeks 


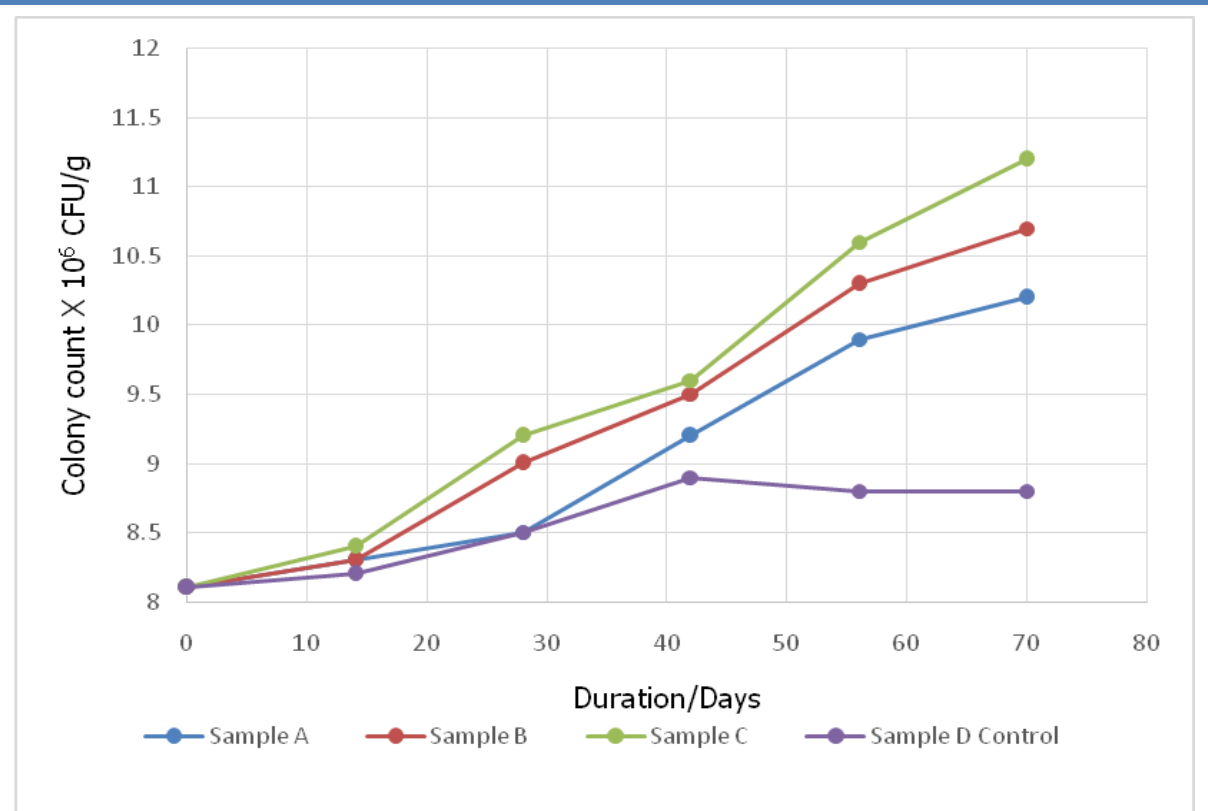

Fig.5. Total Heterotrophic Bacteria Count (THB) in crude oil contaminated soil with different quantity cow dung (Sample A, B and C) and the control treatment without the cow dung (Sample D) for 10 weeks.

The Total heterotrophic bacteria (THB) in hydrocarbon contaminated soil for each treatment option amended with cow dung ranged between 8.1X10 $0^{6} \mathrm{CFU} / \mathrm{g}$ and $11.2 \times 10^{6} \mathrm{CFU} / \mathrm{g}$ (Fig. 4). The un-amended control soil had the Total heterotrophic bacteria count of (THB) ranging between $8.1 \times 10^{6} \mathrm{CFU} / \mathrm{g}$ and $8.8 \times 10{ }^{6} \mathrm{CFU} / \mathrm{g}$. Higher THB counts in oil contaminated soil amended with cow dung might be due to the presence and bioavailability of more $\mathrm{N}$ and $\mathrm{P}$ into the soil that contributed to the stimulation of the microbial flora in the soil. The presence of the macro- and microelements in the cow dung served as a nutrient source for the growth and maintenance of microbial community [13].

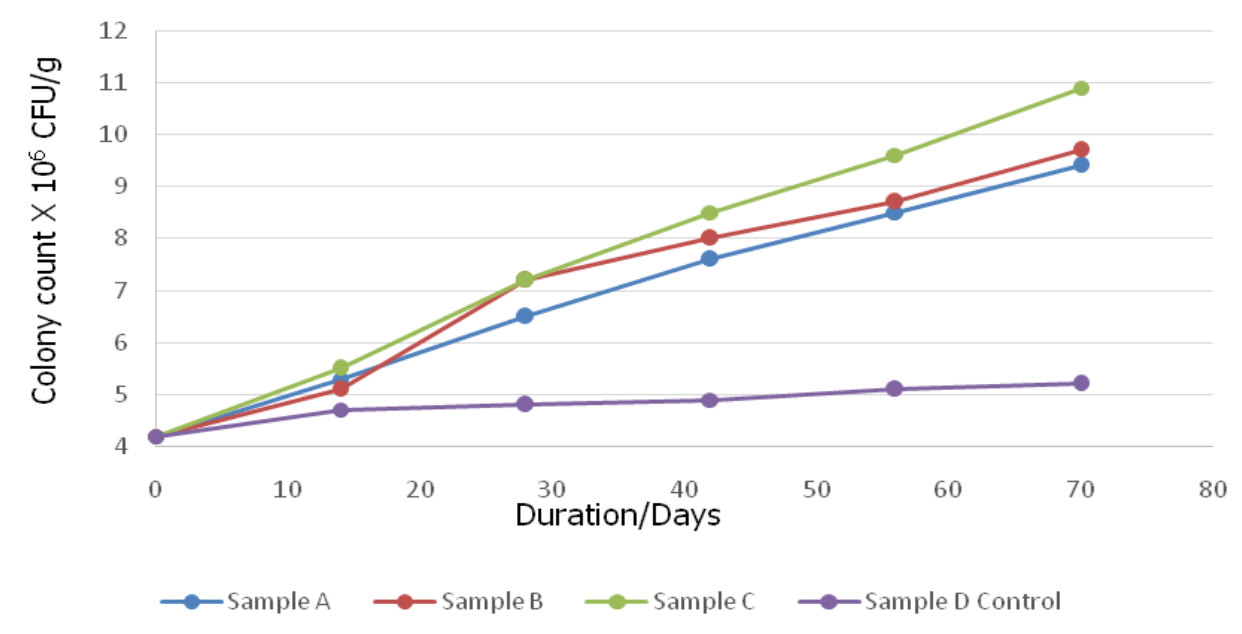

Fig.6. Total Hydrocarbon Utilizing Bacteria Count (THUB) in crude oil contaminated soil with different quantity cow dung (Sample A, B and C) and the control treatment without the cow dung (Sample D) for 10 weeks

The Total Hydrocarbon Utilizing Bacteria (THUB) was also higher in crude oil contaminated soil amended with cow dung (Fig. 6). THUB count in each amended soil ranged between $4.2 \times 10^{6} \mathrm{CFU} / \mathrm{g}$ and $10.9 \times 10^{6} \mathrm{CFU} / \mathrm{g}$ However, the THUB count in un-amended control soil (sample D) ranged from $4.4 \times 10^{6} \mathrm{CFU} / \mathrm{g}$ to $5.2 \times 10^{6} \mathrm{CFU} / \mathrm{g}$, this is relatively far lower compared to each of the amended soil (sample A, B and C).
The higher counts of THB and THUB recorded in all the treatments amended soil (Sample A,B and C) compared to the un-mended control (Sample D) soil might be due to the result of the presence of appreciable quantities of nitrogen and phosphorus in the cow dung, especially high nitrogen content, which is a necessary nutrient for bacterial biodegradative activities $[13,14]$. 
The increase in microbial population counts (Fig. 5 and Fig. 6) in crude oil contaminated soil amended with cow dung is accompanied by significant oil biodegradation (Fig. 1), indicating that the indigenous soil microbes utilized a portion of the carbon supplied by the crude oil as a potential nutrient source.

\section{Conclusion and Recommendation}

In conclusion, Bioremediation can be a viable and effective response to crude oil contaminated soil because it lead to the biodegradation of crude oil contaminated soil as seen from the result. There were visible positively enhanced remediation by the amendment of the crude oil contaminated soil with Cow Dung. This study has demonstrated the potential of cow dung in enhancing the growth of microorganism for the remediation of crude oil contaminated soil.

\section{References}

1. Aina E.O.A., Adedipe E. (2005): Making of the Nigeria Environmental Policy. Federal Environmental protection Agency, Lagos p.329

2. K.H. Baker, D. Herson, Biodegradation, 1st Edition, McGraw Hill Inc., New York, 1994, 9 - 60

3. Okolo, J.C., Amadi, E.N., Odu, C.T.I. (2005) Effects of Soil Treatments Containing Poultry Manure on Crude Oil Degradation in Sandy Loam Soil. Applied Ecology and Environmental Research, 3 (1): $47-53$

4. U.J.J. Ijah, H. Safiyanu, O.P. Abioye, Science World Journal, (2008), 3 (2): $63-67$

5. Nie M, Zhang X, Wang J, Jiang L, Yang J, Quan Z. (2009) Rhizosphere effects on soil bacterial abundance and diversity in the Yellow River Deltaic ecosystem as influenced by petroleum contamination and soil salinization. Soil Biology and Biochemistry,; 41(12): 2535-2542.

6. Rimmer D.L, Vizard C.G, Pless-Mulloli T, Singleton I, Air V.S, Keatinge Z.A.F. (2006) Metal contamination of urban soils in the vicinity of a municipal waste incinerator: One source among many. Science of The Total Environment, 356(1-3):207-216

7. Li X, Liu L, Wang Y, Luo G, Chen X, Yang X, (2013). Heavy metal contamination of urban soil in an old industrial city (Shenyang) in Northeast China. Geoderma,; 192: 50-58.

8. Ijiah U.J.J, Antai S.P (2003). The potential use of chicken dung microorganisms for oil spill remediation. The Environmentalist 23(1):89-95.

9. Oludele, O. E., Ogundele, D. T., Odeniyi, K., \& Shoyode, O. (2019). Crude oil polluted soil remediation using poultry dung (chicken manure). African Journal of Environmental Science and Technology, 13(10), 402-409.

10. Basharudin H. Bioremediation of oil contaminated waste waster using mixed culture. Master Dissertation, Universiti Malaysia Pahang. 2008 Retrieved on April 12, 2011 from http://umpir.ump.edu.my/507/1/BIOREMEDIATION_OF_O IL_CONTAMINATED_WASTEWATER_USING_MIXED _CULTURE_THESIS.pdf

11. Agamuthu P, Tan Y.S., Fauziah S.H. (2013) Bioremediation of hydrocarbon contaminated soil using selected organic wastes, Procedia Environmental Sciences 18 ( 2013 ) 694 702

12. Ijah U.J.J, Safiyanu H. Microbial degradation of Escravos light crude oil in soil amended with chicken dropping and NPK fertilizer, 10th Annual Conference of Biotechnology Society of Nigeria, 2nd -5thApril 1997.

13. Lee K, Park JW, Ahn IS. (2003) Effect of additional carbon source on naphthalene biodegradation by Pseudomonas putida G7. Journal of Hazardous Materials, 105: 157-167.

14. Adesodun J.K, Mbagwu J.S.C. (2008) Biodegradation of waste lubricating petroleum oil in a tropical alfisol as mediated by animal droppings. Bioresource Technology, 99:5659-5665. 